\title{
MAX WEBER: ELEMENTOS PARA UMA BIOGRAFIA SOCIOINTELECTUAL (PARTE II)
}

Michael Pollak*

\section{Fazer política ao fazer ciência}

Os anos anteriores à depressão nervosa de Max Weber, em 1897, são marcados pelo esforço científico e político, concomitante à estabilidade de sua situação profissional e familiar. A nomeação para a Universidade torna-o, definitivamente, independente da casa paterna. Em princípio, essa independência financeira deveria resolver o problema do qual se queixara durante a década de 1880 nas cartas enviadas à prima Emmy Baumgarten: a necessidade de aceitar uma sobrecarga de trabalho em áreas profissionais diversas a fim de chegar à independência material o mais rápido possível. Um alto senso do dever parece determinar sua vida. O que Max Weber vai analisar com assombro em A Ética Protestante e o Espírito do Capitalismo é também a desfiguração de sua própria pessoa por essa ética, ou seja, ser conduzido pelo senso do dever, oposto à tendência natural à preguiça e ao ócio.

No plano pessoal, mesmo seu casamento com Marianne Schnitger não escapa a um ato de dever; ou melhor, Weber está tão impregnado do sentimento de honra, de devotamento e de dever, que dá ao casamento esse aspecto. Enquanto não consegue a independência financeira, não ousa pedir Marianne em casamento. Afinal, é constrangido a isso no momento em que um de seus amigos a pede em casamento. Max Weber cerca seu pedido de várias condições, entre as quais a de um prazo suficientemente longo para que ele atinja a autonomia financeira antes da realização das núpcias. Para que não pesasse sobre essa relação nenhuma sombra de deveres e obrigações passadas, ele exige que sua prima Emmy, que alimentara esperanças de se casar com ele um dia, compreenda e consinta no casamento, assim como sua mãe e sua tia. Insiste, ainda, para que seu amigo-concorrente renuncie voluntariamente ao projeto de casar-se com Marianne (Mitzman 1970:86). 
Quando começa a lecionar, não abandona, porém, as atividades políticas. Ao contrário, a impressão é que Weber, incapaz de reduzir suas obrigações, aumenta as atividades em todos os âmbitos a fim de criar situações de ruptura. É assim que se pode interpretar sua ação nos círculos de Göhres e de Naumann, organizadores da Associação Social-Protestante (Evangelisch-sozialer Verein). Com a ajuda deles, Weber havia organizado uma enquête suplementar para se opor empiricamente às críticas que lhe haviam sido feitas. As atividades desse círculo fazem parte das múltiplas tentativas de reorganização política da burguesia alemã depois que o chanceler Bismarck foi demitido, em 1890, pelo novo imperador Guilherme II. A importância dos aspectos políticos descortinados por Max Weber em sua pesquisa por si só bastariam para explicar sua adesão. De fato, entre 1892 e 1897, Weber tornou-se uma espécie de crítico dos perigos trazidos pela "colonização interna": participa dos congressos anuais da Associação Social-Protestante, adere à Associação Pangermânica (Alldeutscher Verband), que deixará em 1899, e escreve para a imprensa socialcristã e liberal sobre diversos problemas da atualidade. Mas, ao mesmo tempo, suas intervenções, sempre mais polêmicas e desprovidas de qualquer cuidado tático para formar alianças estratégicas a longo prazo, levam a suspeitar de um desejo pessoal de forjar pretextos para uma ruptura, única forma de se retirar do jogo político sem perder a honra. É possível acompanhar suas diversas intervenções que justificam tal hipótese.

Na aula inaugural na Universidade de Fribourg, retoma os temas da conclusão de sua pesquisa, destacando quase exclusivamente as implicações internacionais da questão agrária e o estado da classe dirigente alemã. Max Weber começa o curso com uma definição da nova disciplina (foi nomeado para a cátedra de economia nacional), na qual explicita seu ponto de vista e o erige em pressuposto metodológico e teórico para qualquer trabalho de interpretação; a saber, que é necessário nessa disciplina colocar-se do ponto de vista do interesse do Estado nacional. Como toda realidade econômica é uma luta, a ciência econômica deve participar dessa luta ${ }^{1}$.

\footnotetext{
“Embora sob a aparência de paz, a luta econômica das nacionalidades prossegue [...] em última análise, os processos de desenvolvimento econômico são lutas de poder; os interesses de poder da nação são interesses decisivos se a nação for questionada. A política econômica deve colocar-se a serviço desses interesses: a ciência da política econômica nacional é uma ciência política. É a serva da política, não da política cotidiana a serviço dos grupos e das classes dominantes, mas dos interesses da nação numa política durá-
} 
vel de poder. E, para nós, o Estado nacional não é algo indefinido, que se julga ter elevado quando sua essência está encerrada numa nebulosa mística, mas trata-se da organização terrestre do poder da nação. E, no seio desse Estado nacional, o último critério de avaliação da observação da economia é a 'razão de Estado'. Para nós, esta não corresponde a uma política que preconize a ajuda concedida pelo Estado mais do que a auto-ajuda, como se pode depreender de um curioso mal-entendido, a regulamentação estatal da vida econômica mais do que o livre jogo das forças econômicas. Muito pelo contrário, com esse slogan [a razão de Estado], queremos exigir que cada questão particular de política econômica seja submetida em última instância a um voto decisivo sob o ponto de vista dos interesses econômicos e políticos de nossa nação e de seu representante: o Estado nacional alemão".

A redefinição dos vínculos entre ciência e política permite a Max Weber explicitar de uma vez por todas os pressupostos do discurso da ciência econômica. Na aparência, a subordinação do discurso científico a um fim político introduz uma explicitação que permite resolver o problema do "juízo de valor", tão controvertido durante esse período no Verein für Sozialpolitik. Em vez de introduzir uma espécie de "cláusula de transição" que anuncie a passagem do discurso descritivo-analítico para o discurso prescritivo-político, Weber estabelece, por assim dizer, "o" critério legítimo dessa passagem, e até exige que todos os discursos referentes às ciências econômicas sejam construídos em função desse critério. Nesse trecho, de uma clareza brutal, Max Weber define uma relação entre ciência social e política que a sociologia da ciência funcionalista desde então reinventou sob formas mais eufemísticas, indo da analogia que Talcott Parsons faz entre o trabalho do médico em relação à doença e o do cientista social em relação à crise — ou seja, restabelecer a ordem (a saúde $)^{2}$ - , até a função reservada às ciências sociais por Niklas Luhmann em sua teoria dos sistemas: reduzir a complexidade a serviço da decisão (Luhmann 1968).

Mas, esse trecho de sua aula inaugural constitui também um distanciamento em relação aos discursos "míticos" sobre o Estado e a nação, na época tão correntes em história ou nas disciplinas literárias. Esses distanciamentos permitem a Weber se colocar na tradição da escola histórica, com a qual, porém, rompe parcialmente, de início no plano político e mais tarde no plano científico. Primeiro, ele faz a distinção entre interesses da nação e interesses dos grupos e classes dominantes. Em seguida, ataca o essencialismo da escola histórica (mais exatamente o de Treitschke e seus seguidores) que se perde numa nebulosa mística do Estado. 
Weber continua ligado à escola histórica porque compartilha o mesmo referente metafísico: a nação definida pela língua e cultura comuns. A prova disso está na importância que ele atribui ao problema da colonização interna, além da própria linguagem eivada de racismo cultural quando se refere "aos" poloneses e "aos" russos. Considerar o Estado como instrumento de luta pela sobrevivência e pela expansão nas mãos da nação é também um fator que o liga à escola histórica. Mas, enquanto os historiadores chegam a uma visão organicista do Estado, da qual até os inovadores da geração de Max Weber - como Friedrich Meinecke — não conseguem se afastar, Weber considera o Estado e suas intervenções como objeto específico de análise. Enquanto para Treitschke a visão orgânica do Estado justifica a estrutura de classes e a dominação existentes, e para Meinecke a natureza orgânica leva o Estado a sempre querer crescer por meio da anexação de colônias, Weber aponta as contradições internas das classes dominantes e insiste no perigo dessas contradições para a sobrevivência e a expansão do poderio alemão. Por pertencer a uma disciplina mais "moderna", Weber pode construir um discurso mais "realista" em vista do mesmo objetivo: a manutenção e a expansão do poder da Alemanha. Enquanto o discurso de Meinecke, dentro da tradição da hagiografia histórica, permanece global e abstrato, Weber pode oferecer elementos da análise de classes que mostram as condições internas para a expansão externa. Para compreender essa "revolução" do discurso "moderno", sob o aspecto de sua eficácia operatória, basta comparar a definição de razão de Estado dada por Meinecke com a análise que Max Weber faz da classe dirigente alemã: "É ela [a razão de Estado] que dita ao homem político o que ele deve fazer para conservar a força e a saúde do Estado. Ora, como o Estado é um ser orgânico, cuja força plena só se mantém se puder crescer de uma maneira ou de outra, a razão de Estado indica também os objetivos e os meios desse crescimento" 3.

Ao inverso dessa visão abstrata e idealizada, segundo a qual o homem político age em função de uma razão de Estado, o trabalho empírico havia sugerido a Weber que um homem político por excelência, Bismarck, longe de realizar apenas a razão de Estado, soubera também salvaguardar os interesses de sua classe em detrimento dos interesses da nação, chegando até a destruir as bases sociais da expansão alemã, a organização política e a consciência da classe econômica mais dinâmica - a burguesia.

Max Weber aproveita essa explicação para se distanciar dos "velhos" representantes de sua disciplina, os dirigentes do Verein für Sozialpolitik, favoráveis à intervenção do Estado na vida econômica. Em nome 
do interesse do Estado-nação e de sua expansão, não se pode tomar posição de modo genérico nem pela intervenção do Estado nem pelo livre jogo das forças econômicas. A análise concreta de cada caso é que pode fornecer a resposta. De maneira evidente, Weber pensa nos efeitos negativos do protecionismo aduaneiro sobre a modernização técnica e social da agricultura alemã.

Esses dois distanciamentos e essa definição política da ciência econômica levam Max Weber a organizar a seqüência de suas aulas como um discurso militante. De fato, ele procura saber qual classe social, na Alemanha, reúne as condições necessárias para dirigir o país em função da razão de Estado tal como ele a define. Esse trecho-chave de sua aula inaugural é resultado direto de sua pesquisa sobre os operários agrícolas:

“[...] as grandes propriedades do Estado eram os feudos da classe dirigente prussiana geograficamente dispersa, o viveiro social de altos funcionários, mas com sua decomposição, com o declínio da condição social da velha nobreza fundiária, o centro da inteligência política desloca-se inevitavelmente para as cidades. Esse deslocamento é o elemento político decisivo da evolução agrária do Estado".

A partir de uma confissão de fé pessoal, Max Weber analisa a maturidade política da classe chamada, na sua opinião, a dirigir a Alemanha:

"Sou um membro da classe burguesa. Sinto-me como tal, fui educado de acordo com suas concepções e seus ideais. No entanto, é de vocação (Beruf) da nossa ciência dizer o que não se gosta de ouvir — de dizê-lo para o alto e para baixo, inclusive para a própria classe [...]. Não foi a burguesia, por sua própria força, que criou o Estado alemão. Uma vez criado, houve no comando da nação uma figura de César, feita de cepa diferente da burguesa [...]. É claro que grande parte da alta burguesia deseja o aparecimento de um novo César que a proteja das classes populares ascendentes, tanto quanto da tendência ao reformismo social vinda do alto, tendência esta que lhe parece ser a das dinastias alemãs."

Apenas um esforço contínuo de educação política pode liberar, segundo Weber, a burguesia alemã de seu espírito beato e do caráter filisteu que a impede de conceber a expansão colonial.

Depois desse trecho programático da aula inaugural, Weber caracteriza as outras classes sociais do ponto de vista de sua maturidade política, o que o distingue nitidamente dos "socialistas de cátedra" e de todos 
aqueles cuja ação científico-política é mais inspirada pelos bons sentimentos do que pelo espírito de poder.

No que se refere ao proletariado, ele rejeita o medo burguês diante dessa classe ascendente, mas critica sua direção política aprisionada em uma retórica radical do passado, contraditória com sua inofensiva ação política:

\begin{abstract}
"Economicamente as camadas mais altas da classe operária pensam muito mais do que o querem admitir as classes dominantes. E é justo que essa classe reivindique a liberdade de defender seus interesses na forma de luta organizada para obter o poder econômico. Mas politicamente essa classe é bem menos segura do que costuma insinuar a corja de jornalistas que quer monopolizar sua direção. Nos grupos de burgueses decadentes, há quem goste de brincar com lembranças do século passado. Desse modo, eles conseguiram de fato assustar alguns espíritos angustiados que os vêem como descendentes da Convenção. Mas, na realidade, são muito mais inofensivos do que parecem a eles próprios [...], não passam de lastimáveis artesãos da política."
\end{abstract}

Lembrando e redefinindo a tarefa da política nacional em um sentido imperialista, Max Weber invoca a classe operária inglesa e, em menor proporção, a francesa como exemplos positivos do ponto de vista da maturidade política, pois essas classes, ao contrário do caso alemão, adotaram nitidamente os objetivos da política de poderio nacional.

“É preciso entender que a unificação da Alemanha foi uma brincadeira de criança cometida na velhice pela nação. Melhor seria ter evitado essa brincadeira custosa, se ela fosse o ponto final e não o ponto de partida de uma política alemã de poderio mundial. O lado perigoso de nossa situação é o seguinte: como portadoras dos interesses de poder da nação, as classes burguesas parecem envelhecidas, ao passo que não se percebe sinal de suficiente maturidade na classe operária para que esta possa substituir a burguesia [...]. O perigo não está no lado das massas. Em última instância, a essência do problema da política social não está na questão da situação econômica dos dominados, mas na qualificação política das classes dominantes e ascendentes. A finalidade de nosso trabalho de política social não é a de tornar o mundo feliz, mas de unificar socialmente a nação $[\ldots]^{\prime \prime}$.

Em seus pares mais velhos do Verein für Sozialpolitik, ele reprova o fato de serem filisteus sem educação política: 
"O ladrar estereotipado do coro crescente dos - com perdão da expressão - políticos sociais da floresta e do campo (Wald und Wiesen Sozialpolitiker) é prova do oposto à educação política, isto é, a pieguice, humanamente amável e estimada, mas que não passa de um comportamento filisteu, que crê ser possível substituir ideais políticos por ideais éticos, identificando estes últimos com a esperança de felicidade inofensiva e otimista".

No fim da aula, diz aos pares de sua geração:

"Apesar da enorme miséria das massas da nação, que pesa na consciência social mais sensível da nova geração, devemos reconhecer com clareza: a consciência de nossa responsabilidade diante da história tem hoje peso ainda maior sobre nós. Nossa geração não chegará a ver se a luta que travamos terá bons frutos, se nossos descendentes nos reconhecerão como seus antepassados. Só com uma condição conseguiremos nos livrar do destino que pesa sobre nós; a saber, o de sermos os epígonos de uma grande era política. É preciso que nos tornemos outra coisa: precursores de uma era ainda maior".

Percebe-se em sua aula inaugural uma estrutura retórica semelhante à de sua conclusão na pesquisa sobre os operários agrícolas, mas o caráter da seqüência é outro: depois de uma curta descrição resumindo a enquête, vem a passagem explicativa dos valores que sustentam a análise, ou seja, a razão de Estado que obriga à expansão imperialista. Cada vez que ele examina uma classe social é sob o aspecto da maturidade política dessa classe diante de tal objetivo, para o que vai utilizando palavras cada vez mais dramáticas e personalizadas - de "razão de Estado" até "responsabilidade diante da história".

Ao constatar a imaturidade política de todas as classes alemãs e ao criticar os falsos temores que elas têm entre si, ele atribui ao grupo de professores de sua geração a tarefa de educação política, a mais importante no momento. Em resumo, reivindica o poder também para si próprio. A explicitação da função política da ciência econômica permite a construção de um discurso de pretensão científica, mas que contém, de fato, inúmeros elementos de análise realista, um mínimo de elementos descritivos e um máximo de elementos de ação.

Ao servir-se da cátedra como um palanque, ao suscitar o vivo interesse e o aplauso de homens políticos inovadores que, como ele, identificam a questão nacional como problema-chave da Alemanha, ele interfere de modo ativo nas discussões da Associação Social-Protestante de Naumann, provocando uma cisão entre as correntes social-cristã e social- 
nacional que existem em torno de Naumann e de Weber. Mas Weber não encontra eco quando exige que esta corrente seja organizada com base na classe burguesa. Essa ruptura política não chega a abalar sua amizade com Naumann (Weber 1926:257).

Um ano depois de sua nomeação para a cátedra de economia política na Universidade de Heidelberg, pela primeira vez Weber assume, em 1897, o conflito que o opõe a seu pai. Este não queria que a esposa fosse sozinha passar as férias na casa da família do filho. Max Weber toma partido da mãe e expulsa de sua casa o pai que tinha ido junto com a mulher, contra a vontade dela. Pouco tempo depois, o pai morre (Mitzman 1970:149 e ss.).

Semanas depois do enterro, Max Weber enfrenta a primeira depressão nervosa. As causas dessa depressão não ficam muito claras. O excesso de trabalho e o fracasso político devem ter contribuído para isso tanto quanto as circunstâncias da morte do pai. Até 1903, Weber não consegue trabalhar. São anos em que faz muitas viagens, sobretudo à Itália.

Durante esse período, Max Weber tenta várias vezes retomar as aulas. Cada tentativa é um fracasso, seguido de recaída na depressão. Em 1899, a Universidade lhe concede uma primeira licença, que será renovada várias vezes. Pouco antes da depressão, Weber tinha dúvidas sobre qual seria a carreira mais apropriada a seu feitio e competência; dizia a Lujo Brentano: "Os êxitos da carreira acadêmica que obtive sem procurar e sem reivindicar deixam-me indiferente e não me oferecem resposta quanto a saber se esta é de fato a carreira que me convém (Weber 1926:257).

A doença resolve o problema. A partir de então, a carreira política está fora de cogitação. Sem coragem, Max Weber não pode colaborar nem no jornal fundado pelo colega político, F. Naumann. Vários depoimentos e cartas de Weber mostram toda a força de sua moral protestante que o leva a viver com vergonha a doença, na medida em que ela cria nova dependência material. Ele deplora: "a pressão psicológica desta situação indigna em que se recebe dinheiro sem nada fazer em troca, e o sentimento [...] de que, aos teus olhos como aos meus e aos de todo mundo, só o homem com uma profissão goza de consideração". Nessa situação, Max Weber pede ao Ministério que aceite sua demissão, o qual, em vista da notoriedade do professor, a recusa. Só em 1903, o Ministério aceita sua aposentadoria e o nomeia professor honorário, incluindo uma carga mínima de aulas.

Essa solução libera Max Weber do sentimento de vergonha ligado à doença como também das preocupações materiais. A partir de 1903, ele 
pode voltar a trabalho. Na nova fase de atividade intelectual, colhe os frutos da relativa liberdade oferecida pelo período de doença - a liberdade, sobretudo, de dispor de tempo e lazer para aventurar-se fora do próprio campo de atuação, fechado e definido pelas regras de especialização do trabalho universitário. De fato, durante a doença, Max Weber pôde realizar uma série de leituras desordenadas que muito o ajudam a estruturar seu programa de trabalho comparativo, o qual percorre a realidade social em todos os sentidos de tempo e espaço: "a vontade de devorar uma mistura fabulosa de livros falando de conventos medievais, Aristóteles, Rousseau, Voltaire, Montesquieu, Taine" (Weber 1926:290).

\section{A doença: condição de distanciamento}

Quando, em 1903, Max Weber retoma o trabalho sua situação de "doente" limita e orienta suas atividades, conferindo-lhe - científica e politicamente - a categoria de um "fora de jogo". Tal situação lhe possibilita um alto grau de independência, que explica não apenas o conteúdo de suas atividades, mas também seu estilo. Como professor honorário, continua a fazer parte do meio universitário, sem dispor no entanto dos instrumentos de poder conferidos a seus membros. Sem direito a sancionar exames, Weber é destituído do instrumento de poder social do docente, com o qual podia intervir no mercado de trabalho. Como já não participa das deliberações e votações no conselho universitário, Weber perde toda a influência sobre o futuro institucional. Com dupla razão, esse afastamento aumenta-lhe a independência profissional. Em primeiro lugar, por gozar de uma renda estável, Weber encontra-se em uma espécie de ano sabático permanente, com tudo o que isto representa de tempo disponível e de liberdade. Em segundo lugar, a perda de poder no seio da instituição o libera de um certo número de obrigações. Sem ser forçado a situar-se em relação a uma disciplina, pode dar asas à curiosidade. Depois da já incomum trajetória intelectual anterior — do direito às ciências econômicas, passando pela história - Weber pode continuar essa viagem desordenada entre as fronteiras bem delimitadas da Universidade. Mais importante ainda: a ausência de poder institucional o libera das regras de cortesia vigentes no mundo universitário, que não passam de modos de manter a conformidade, para não dizer o conformismo acadêmico e intelectual.

Essa posição marginal, "fora de jogo", mas ao mesmo tempo dentro, caracteriza também sua ação política. A ligação com Friedrich Naumann 
o coloca em uma atividade política destinada ao fracasso, cuja única função, mesmo no interior desse campo específico, será a da "crítica interna". De fato, Friedrich Naumann foi, na época, uma figura política ouvida com atenção, sem nunca, porém, ter sido de fato admitido no jogo do poder. Depois de vários fracassos eleitorais e de uma breve passagem de 1907 a 1912 - como deputado no Reichstag, Naumann concentra-se, sobretudo, na atividade jornalística. Em certo sentido, é, assim como Weber, paradigma tanto do intelectual político de pouco sucesso, como do professor universitário com ambições políticas insatisfeitas, figura freqüente na história do liberalismo alemão até hoje.

Essa posição específica, que podemos caracterizar pelo termo americano in-betweenness (Pollak 1986:75), abre caminho para uma solução do problema da explicitação das relações entre política e ciência, totalmente oposta àquela que Weber havia proposto em sua aula inaugural de Fribourg. Ao definir a ciência (econômica) como serva da política - e esta, por sua vez, definida pelos interesses de poder da nação representada pelo Estado - Max Weber havia deduzido dessa posição, com clareza, pressupostos "legítimos" para a interpretação. Depois de 1903, Weber inverte a problemática. Sob a influência de obras especializadas de lógica e dos neokantistas Windelband e Rickert, seu colega e amigo íntimo, Weber submete os textos dos antigos mestres da escola histórica em ciências econômicas não mais à crítica política - como fizera em suas contribuições no Verein für Sozialpolitik e na aula inaugural —, mas sim à crítica lógica. Seu primeiro texto referente à teoria da ciência é uma crítica minuciosa de Roscher e de Knies (Weber 1903). No primeiro autor, critica sua "inconseqüência": depois de ter rompido com a teoria clássi$\mathrm{ca}$, Roscher usa o método histórico e a pesquisa empírica apenas para voltar ao projeto de construção de leis formalistas sobre bases mais amplas. Roscher mantém, portanto, alguns pressupostos da teoria clássica, sobretudo, o de construir leis transhistóricas. Quanto a Knies, sua observação empírica não chega automaticamente à possibilidade de construir as regularidades da vida econômica e social, como previa em seu projeto. Em ambos, transparece um princípio organizador da vida econômica e social: os valores de um humanismo de inspiração protestante. Esse pressuposto de um mito fundador da vida econômica dispensa-os de uma reflexão conceitual rigorosa.

Nesse artigo publicado em três números consecutivos de uma das mais conceituadas revistas de ciências econômicas, dirigida por Gustav Schmoller, Weber começa a inverter sua problemática de demonstração. Tal inversão tem importantes conseqüências. Primeiro, o que se espera 
do autor de um texto científico não é apenas que explicite seus valores, mas que faça todo o esforço para não confundir esses valores com a análise científica, isto é, manter separado seus valores de seus textos analíticos. Segundo, o problema da análise científica não se reduz à explicitação; esta é o ponto de partida da construção conceitual. Finalmente, a construção do argumento científico deve seguir vias diversas daquelas do argumento político.

Nos textos anteriores de Max Weber, percebia-se a linha de argumentação típica da retórica política: da descrição passa-se à prescrição e, progressivamente, as conclusões imagináveis vão sendo reduzidas à única conclusão desejável do ponto de vista do autor. Porém, nos textos científicos de Weber escritos mais tarde, ele se preocupa com a clareza descritiva e analítica, não formula conclusões em termos de ação, e — à guisa de conclusão - inúmeros textos de Weber terminam em termos prospectivos, que destacam não uma única solução mas diversos desdobramentos possíveis.

A evolução política alemã anterior à Primeira Guerra Mundial ajuda a manter Weber em seu afastamento do ativismo político, sobretudo porque qualquer aborrecimento pode levá-lo a uma recaída na depressão. De certa forma, a política alemã da época serve de aviso para ele e de lição dolorosa a respeito da eficácia que pode ter o discurso político-universitário militante.

Max Weber reconhece que apenas parte de sua mensagem da aula inaugural foi ouvida, ou seja, a vontade de a Alemanha conquistar um império colonial, a exemplo da Inglaterra e da França. Na aula, Weber havia associado a busca desse objetivo a uma mudança das forças dirigentes alemãs, à emancipação da burguesia e à sua libertação do autoritarismo feudal mantido pela casta aristocrática que, para lutar contra a própria derrocada, apoiava-se no aparelho de Estado. Ora, o que Weber constata na realidade se assemelha a um arranjo entre as velhas classes dirigentes e a burguesia ascendente que, em troca da defesa de seus interesses econômicos, desiste das pretensões políticas e isto, ainda com maior facilidade, porque as estruturas feudais do Estado alemão a protegem da social-democracia, cada vez mais forte eleitoralmente. Weber é obrigado a constatar que o uso político da produção científica é seletivo e que o autor não tem como influir nesse uso. O regime autoritário de Bismarck havia, segundo Weber, impedido a educação política e a seleção de "homens políticos" no sentido "nobre" do termo, isto é, à altura da tarefa. Mas, ao menos, Bismarck fora um estadista com visão clara dos interesses do Estado em política exterior. Já o reinado pessoal de Gui- 
lherme II continha todos os riscos do autoritarismo exercido por um personagem vaidoso e imprevisível. Sua política quando da crise marroquina em 1906, bem como a política de germanização das populações polonesas eram provas disso. Na correspondência com Friedrich Naumann, Max Weber insiste na necessidade de atacar o Imperador ad personam, a fim de tornar possível a democratização da Alemanha (Baumgarten 1964). O interesse que, em 1905, desperta nele a Revolução Russa é decorrência de sua preocupação com a Alemanha. Com a ajuda do refugiado Bogdam Kistiakkovski, especialista em direito público, Weber aprende russo. Em suas análises do processo revolucionário russo, ele compara o czarismo ao reinado personalista de Guilherme II na Alemanha (Weber 1906a; 1906b). Mas essas intervenções políticas são periféricas em relação ao desenrolar de sua obra científica.

Esta permanece ligada à história de uma revista, a Archiv für Sozialwissenschaft und Sozialpolitik. Antes da depressão nervosa, Max Weber havia escrito para as coleções do Verein für Sozialpolitik, assim como para revistas de prestígio nas áreas de história, direito e economia: Historische Zeitschrift, Zeitschrift für das gesamte Handelsrecht, Jahrbuch für Nationalökonomie und Statistik. Sua crescente oposição aos velhos mestres da escola histórica, sua concepção epistemológica apresentada pela primeira vez na crítica a Roscher e Knies, assim como sua posição universitária bastarda afastavam-no dos grandes circuitos do mercado de publicações.

Por várias vezes, ele participa das reuniões do Verein für Sozialpolitik como ouvinte, sem intervir nas deliberações. Nessas condições, a compra do ex-Archiv für soziale Gesetzgebung und Statistik por seu colega economista Edgar Jaffé lhe oferece um meio de publicar em um círculo de amigos, ao abrigo de tensões e conflitos que não pode enfrentar por causa da saúde frágil. Weber é levado a essa tarefa por intermédio de sua ex-aluna, Else von Richthofen, que se casa com Edgar Jaffé. Graças à fortuna pessoal, Edgar Jaffé, amigo e colega de Max Weber, consegue recuperar a prestigiosa revista em decadência. Marginalizado do círculo das ciências históricas por força de suas tendências marxistas (em 1918 fará parte do governo revolucionário da Baviera), Edgar Jaffé não desempenhou papel científico de destaque. Mas, seu espírito eclético, o gosto e a sensibilidade pelas modas intelectuais em evolução tornavam-no um excelente pólo aglutinador para todos os que tinham idéias divergentes dos dogmas da velha geração. Else von Richthofen, partidária como Marianne Weber do movimento feminista, fora uma das primeiras mulheres na Alemanha a defender tese de doutoramento. Interessada mais diretamente nos modos específicos de exploração das operárias, havia opta- 
do por uma carreira de acordo com suas opções políticas feministas: inspetora do trabalho. Para ela, como para muitos outros alunos, Max Weber continuava a ser, apesar da doença, um personagem carismático: de fato, sua crítica da estrutura de classes, sua profissão de fé patriótica, era o quadro de pensamento ideal para todos aqueles e aquelas que associavam as aspirações reformadoras e democráticas ao desejo de projeção internacional. O terceiro dirigente da revista, Werner Sombart, também era um herege da velha geração e seu destino se cruzara várias vezes com o de Max Weber. Fora ele quem havia obtido o cargo de conselheiro da cidade de Bremen, ao qual Weber concorrera em 1891. Fora ele quem Weber propusera como seu substituto na Universidade de Heidelberg, mas que — provavelmente por motivos políticos — não havia sido aceito pelo governo.

O editorial do primeiro número de reaparecimento da revista, em 1904, redigido por Weber, é um discurso-programa tanto da revista quanto das suas intenções de trabalho (Weber 1904). É nesse texto que define pela primeira vez sua concepção da separação entre juízo de valor e trabalho de pesquisa. Apóia-se nos trabalhos de Windelband, de Dilthey e de Rickert, e apresenta sua própria posição epistemológica, a construção conceitual de idealtypes. Anuncia igualmente o campo temático da revista, que corresponde ao programa a que ela se propõe: esclarecer com a ajuda de todas as disciplinas as origens do capitalismo, das diferentes configurações econômicas e do papel do Estado na atividade econômica. Seu intuito é, sobretudo, considerar todos os fatores, inclusive os nãoeconômicos, em particular os culturais e os religiosos. Os argumentos apresentados nesse texto reaparecem na maioria dos trabalhos de Max Weber sobre a teoria da ciência. Desenvolvidos em resenhas sobre livros ou autores - como o historiador Eduard Meyer e o economista R. Stammler —, tais argumentos são, em parte, textualmente retomados em seu relatório sobre a querela de juízos de valor que preparou para a reunião anual do Verein für Sozialpolitik em 1913 — tendo sido publicado em 1918 - , assim como no discurso sobre o ofício e a vocação de cientista, proferido aos alunos da Universidade de Munique no início do ano de 1919.

Max Weber dedica seu primeiro texto importante na nova revista à relação entre religião e economia. Como todos os seus textos posteriores, A Ética Protestante e o Espírito do Capitalismo nunca foi publicado sob a forma de livro durante a vida de Max Weber. Esse texto é o primeiro exemplo da aplicação de seus preceitos metodológicos anunciados no editorial do primeiro número da revista e apresenta o vasto projeto de 
comparação sistemática entre as éticas econômicas das grandes religiões. Tal projeto comparativo é uma decorrência direta do procedimento metodológico que visa à construção conceitual de idealtypes.

As preocupações com o fenômeno religioso, já presentes em sua juventude, voltam ao primeiro plano dos interesses de Max Weber após sua relativa cura. Um dos colegas mais próximos, Ernst Troeltsch, é o parceiro preferido de discussão. Professor de teologia, amigo íntimo do casal Weber, com quem partilha a mesma casa a partir de 1910, Troeltsch é adepto do nacional-liberalismo tradicional e não segue, no início do século, o engajamento social e democrático dos Weber. A partir de 1905, um círculo de discussão que reúne economistas, políticos e teólogos é criado em Heidelberg por iniciativa de von Deissmann, político do nacionalsocialismo, amigo de Friedrich Naumann, que também participa dessas reuniões. Windelband, Jellinck, Rathgen, Troeltsch e Weber estão presentes. Mesmo sem dispor de fontes escritas nem de atas, decerto um dos temas de discussão do círculo terá sido o dos efeitos econômicos e políticos provocados pela diversidade religiosa na Alemanha, ponto de partida empírico das reflexões de Max Weber sobre a ética protestante. Em sua biografia, Marianne Weber relata que o marido não concluiu a comparação sistemática entre as religiões cristãs, sobretudo a comparação entre protestantismo e catolicismo, porque esse campo já estava ocupado por Troeltsch. Entretanto, as preocupações político-práticas que estão na origem do trabalho de Weber sobre a ética protestante aparecem nas notas em que ataca seu meio profissional com estilo bem polêmico. De fato, destacar a importância da ética protestante não apenas para a emergência do capitalismo, mas ainda para o procedimento racional em todos os domínios, equivale a denunciar implicitamente a tradição estatista protestante e da escola histórica. Esse "estatismo", longe de ser social ou socialista, vem favorecer a burocratização, outro fruto da ética protestante que consegue transformar a realidade social em "prisão" (Mitzman 1970:207 e ss.).

Esse vínculo entre a análise da religião, da economia, da política e do Estado será desenvolvido na sociologia do direito e da administração.

Politicamente a controvérsia que, em 1909, em uma reunião do Verein für Sozialpolitik, realizada em Viena, o opõe a Gustav Schmoller enfatiza esse ponto: para este último, a defesa de uma política social do Estado em favor dos operários justificava a restrição dos direitos de associação coletiva. Em nome do interesse nacional, um Estado burocratizado, forte e social, nada mais é do que a barreira aos movimentos de reivindicação das classes sociais dominadas. Depois de haver detonado a 
evolução capitalista, o espírito protestante dos historiadores-economistas, brilhantemente esboçado por Max Weber nos textos sobre Roscher e sobre Knies, toma a defesa do Estado social, mais preparado para proteger o capital e a classe dirigente tradicional. Nessa mesma reunião, Max Weber junto com seu irmão Alfred defendem ardorosamente os direitos de associação dos operários bem como soluções não provenientes do Estado para a questão social.

Embora o desligamento das obrigações na Universidade lhe forneça, ao menos em princípio, toda a liberdade para dedicar-se integralmente a seus escritos, estes se constroem através de controvérsias nas quais ele se deixa envolver ou envolve outros. É como se, para desenvolver seu programa de trabalho e para esclarecer suas posições, Max Weber tivesse necessidade não só da comunicação, mas da polêmica. Tentado em certos momentos da vida a dedicar-se à contemplação, ele volta sempre à arena do combate intelectual e político. A elaboração de sua teoria da ciência também é entremeada de conflitos com professores, durante os quais não hesita em levar seus opositores aos tribunais a fim de constatar "a verdade".

O estilo de sua escrita mostra essa mesma disposição. Muito didático, a repetição nele aparece como importante elemento retórico. Aliás, Marianne Weber caracteriza muito bem esse estilo ao situar sua razão de ser na riqueza e extensão dos argumentos que Weber queria incluir a todo custo:

“E ele não dá nenhuma importância à forma de apresentação das riquezas de seu espírito. Quando libera a corrente de suas idéias, brotam tantas idéias das comportas de sua mente, que não é fácil conter tudo isso em uma frase bem estruturada. Ademais, ele quer terminar logo o trabalho e expressar-se da forma mais curta possível porque são muitos os problemas existentes na realidade que o afligem. Que limitação existe no pensamento discursivo, que não consegue expressar ao mesmo tempo várias linhas de idéias ligadas entre si! É por isso que tanta coisa tem de ser contida em longas frases encadeadas, e tudo o que aí não cabe tem de ser remetido a notas. Que o leitor faça o mesmo esforço que ele quando escreve!" (Weber 1926:350).

Mesmo tocando em cheio na questão da sintaxe weberiana, Marianne não assinala toda a importância do dispositivo científico das notas. Na verdade, essas "referências" quase nunca servem para reconhecer uma dívida intelectual. Abundam, ao contrário, as demarcações, refutações e a antecipação de eventuais contra-argumentos. De fato, as citações de 
Max Weber constituem uma espécie de fortaleza que deve colocar o texto propriamente dito ao abrigo de qualquer crítica dos concorrentes. Essas notas, marcas de controvérsias científicas, se dirigem a seus pares, entre os quais estão Lujo Brentano, Werner Sombart, Karl Menger, Gustav Schmoller. Excelente jurista, Weber argumenta como nos processos que teve de fato contra outros colegas. Suas notas podem ser lidas como o texto da defesa em um processo imaginário, no qual ele quer convencer o juiz e os jurados — os leitores — de sua argumentação.

É por meio desses debates e controvérsias, com ou sem a presença física dos adversários, que Weber constrói sua obra, empreende um trabalho de objetivação que toma forma nos idealtypes. É no domínio religioso que esse trabalho se realiza de forma mais completa. Em compensação, percebe-se que sua teoria da ciência contém elementos de uma sociologia científica comparável à sua análise da religião, mas que continua sobredeterminada por conceitos morais. No domínio político, ao qual retorna depois de 1914, seu trabalho de objetivação também permanece inacabado. É possível retraçar os motivos desses vários graus de objetivação, dentre os quais a falta de tempo é uma razão evidente. Dessa forma, pode-se tentar apresentar não só as condições do pensado, mas os limites do pensável no espaço-tempo em que se insere Max Weber.

\section{Da ética protestante à sociologia religiosa}

Publicados sob a forma de artigos na Archiv entre 1905 e 1919, os textos sobre a sociologia das religiões constituem a mais perfeita ilustração da metodologia weberiana; a saber, a construção de idealtypes, ligada à descrição histórica, que serve para estabelecer a distância entre as manifestações reais, os Realtypes, e o Idealtype. Ao mesmo tempo, a leitura desses textos mostra o caráter temporário e, portanto, relativo dos idealtypes, antes instrumentos do que resultados da pesquisa. Do mesmo modo, esses artigos ilustram a dinâmica interna do método comparativo, que amplia constantemente o campo empírico a ser submetido à análise com o intuito de aperfeiçoar os idealtypes.

O primeiro texto sobre a sociologia religiosa, o que trata da "ética protestante", deve, ao menos em parte, sua problemática ao contexto político-intelectual do círculo reunido em Heidelberg em torno de von Deissmann, bem como à longa viagem realizada por Max Weber junto com outros professores alemães aos Estados Unidos, por ocasião da Exposição Universal de 1904 em St. Louis. A primeira parte de seu estudo foi escrita 
antes; a segunda, depois da viagem aos Estados Unidos. Hugo Münsterberg, de origem alemã, professor de psicologia e de filosofia na Universidade de Harvard, teve um papel-chave nas relações universitárias americano-alemãs na virada do século. O congresso científico organizado no momento da Exposição Universal de 1904 foi a ocasião para que um número expressivo de professores alemães estabelecesse contatos pessoais e se apresentasse ao público americano. Ernst Troeltsch e Ferdinand Tönnies faziam parte da delegação alemã. Apesar de seu prestígio na Alemanha, essa estada de Weber não deixou marcas na sociologia americana. (Ainda com a saúde abalada, Weber evitava toda manifestação de caráter mundano.) Além disso, tratou de um assunto econômico, os problemas agrários, diante de um público composto sobretudo de sociólogos, entre os quais os da Escola de Chicago. Em compensação, os Estados Unidos provocaram em Weber uma impressão que muito influiu em suas pesquisas. Weber passou quatro meses nos Estados Unidos, onde se interessou de forma especial pela organização das seitas protestantes, pela filantropia e pela caridade organizadas, assim como pelo papel desempenhado por essas organizações religiosas enquanto grupos de pressão sobre outras organizações mais formais, como os sindicatos. Assim, em Chicago, Weber encontra Forence Kelley, que, apoiado no socialismo de um grupo religioso, lutava contra a corrupção dos dirigentes sindicais. Visita também um de seus sobrinhos, descendente de refugiados político-religiosos, em Oklahoma. O que interessa e empolga Max Weber é a importância, nos Estados Unidos, da influência germânica mediatizada pela cultura religiosa, ainda mais viva e menos secularizada que no protestantismo alemão (Weber 1906c). A admiração, e até o fascínio, que exerce sobre Weber a força transformadora do pensamento protestante, de um lado, e a angústia da organização racional de mundo que ela gera, de outro, dão origem à tensão que perpassa toda a sua obra entre a fetichização da modernização-racionalização do mundo e o pessimismo cultural que teme o desaparecimento da liberdade individual. Em uma análise diacrônica, esses dois pólos correspondem à primeira fase, a da racionalização, que libera o indivíduo das imposições sociais tradicionais (o famoso "fundo individualista no movimento" já encontrado em sua enquête no meio agrícola no fim do século XIX), e à fase posterior, em que a burocracia cria a "prisão" dos constrangimentos atuais. Na análise sincrônica, esses dois pólos representam o Novo Mundo dinâmico dos Estados Unidos e o Velho Mundo da Alemanha. Mas, vamos acompanhar a argumentação na Ética Protestante.

Herdeiro da tradição da escola histórica, Weber começa pela constatação de um problema: a posição dominante dos protestantes na vida eco- 
nômica alemã. Aborda seu objeto de estudo de modo indutivo, que vai se apresentando aos poucos no texto. Depois de uma primeira comparação sincrônica com outros fenômenos de disparidades econômicas (regionais, minorias nacionais), Weber constata a pertinência do fator religioso. Mas logo adverte contra interpretações apressadas, pois, inicialmente, a Reforma havia sido um movimento de moralização religiosa, "ela significava a substituição de uma autoridade muito frouxa [...] por outra, que penetrava todos os domínios da vida pública ou privada, impondo uma regulamentação do comportamento muitíssimo pesada e severa" (Weber 1905). Ao mesmo tempo, a criação de riqueza e a herança não explicam por si sós a posição econômica dominante dos protestantes na Alemanha. Com base em estatísticas referentes à educação, Weber consegue mostrar uma sobre-representação, nas escolas superiores, de filhos de famílias protestantes e de uma sub-representação de católicos que, além disso, freqüentam escolas tradicionais e não as escolas técnicas e comerciais. Fato ainda mais surpreendente, os católicos, minoria na Alemanha, não apresentam, como é costume no caso de minorias excluídas dos cargos de decisão política, interesse pelas atividades econômicas. Weber procura, pois, os fatores que expliquem essa diferença nas "particularidades mentais [...] inculcadas pelo ambiente religioso da comunidade ou do meio familiar".

A seguir, Weber discute, para rejeitá-lo, o argumento corrente que opõe o "distanciamento do mundo" do catolicismo, seus elementos ascéticos, ao materialismo protestante, conseqüência da secularização de todos os domínios da vida pelo protestantismo. Bem ao contrário, ele mostra um profundo parentesco entre espírito comercial e piedade cristã em certas tendências protestantes, em particular no pietismo e no calvinismo. Mas, as seitas protestantes distinguem-se entre si pela maior ou menor presença desses dois aspectos. Depois dessa primeira rodada comparativa entre diferentes religiões e seitas,

“[...] ocorre-nos um grande número de correlações possíveis, vagamente percebidas. Nossa tarefa será então de formular o mais claramente possível o que só percebemos de forma ainda confusa diante da inesgotável diversidade de fenômenos históricos. Será necessário abandonar o campo das representações vagas e gerais, para penetrar nos traços específicos e nas diferenças desses universos religiosos que constituem historicamente as diversas expressões do cristianismo".

O segundo capítulo, destinado à definição do problema, analisa a expressão "espírito do capitalismo". Com base em citações de Benjamin 
Franklin e de Jacob Fugger, Weber apresenta uma justificação ética própria ao capitalismo moderno ocidental, que está ausente em outras situações de acumulação de tipo capitalista "na China, na Índia, na Babilônia, na Antiguidade e na Idade Média". Nessa ética, valores como honestidade, pontualidade, frugalidade são valorizados por sua utilidade para ganhar dinheiro, que se torna "o fim a que o homem se propõe; deixa de lhe ser subordinado como meio de satisfação das necessidades materiais". Mas tal ética, antes de se tornar um fenômeno de massa, só pode se impor por meio de conflitos importantes contra o "tradicionalismo":

"O homem não deseja, por natureza, ganhar cada vez mais dinheiro, mas deseja, apenas, viver segundo seus hábitos e ganhar o dinheiro necessário para isso. Em toda parte onde o capitalismo implantou sua obra de crescimento da produtividade do trabalho humano pelo aumento de sua intensidade, esbarrou na resistência obstinada desse leitmotiv do trabalho da economia pré-capitalista".

Depois de insistir nos limites da pressão sobre os salários como modo de acumulação, sobretudo nas indústrias cuja aparelhagem técnica exige a qualificação e a responsabilidade dos operários, Weber mostra que o trabalho dependente também é conduzido e sustentado por uma ética: a "vocação" (Beruf). Em compensação, as novas riquezas são, quase sempre, conseguidas por novos-ricos nas fábricas nascentes, ou por jovens empresários "que tornam mais racional a articulação entre a produção e seu rigor, e a comercialização". A concorrência que se segue elimina aqueles "que não acompanhavam o passo". Mas, na maioria das vezes, esses inovadores não foram nem especuladores nem aventureiros: "foram educados na dura escola da vida, calculistas e arrojados". Interrogados a respeito do "sentido" de uma atividade sem descanso a qual os obriga a concorrência

“[...] talvez respondam, se souberem dizer alguma coisa: trabalho para meus filhos e meus netos! Mas, quase sempre - porque este motivo não lhes é específico, aparece também entre os tradicionalistas - vão responder, com mais exatidão, que o negócio, com a atividade incessante que exige, se tornou simplesmente indispensável à sua vida. De fato, essa é a única motivação possível ${ }_{i}$ considerada porém do ponto de vista da felicidade pessoal, ela mostra também quão irracional é a situação em que o homem existe em função da empresa, e não o contrário". 
O sistema capitalista, longe de ser o fruto de "arrivistas e aventureiros", precisa dessa dedicação à vocação (Beruf) de ganhar dinheiro. O fundamento do racionalismo econômico moderno deve ser encontrado no fato de o indivíduo sentir uma obrigação moral que dá base ética e justificativa à atividade empresarial e ao trabalho transformados em "vocação" (Beruf). Esse segundo trecho de definição do objeto estudado conclui pela diferença entre a racionalização oriunda do espírito do capitalismo e a filosofia racional, puramente secular, do século XVIII, que

“[...] não encontrou seu único nem principal campo de preferência nos países onde o capitalismo estava mais desenvolvido. Nos países de catolicismo romano, o voltaireanismo permanece, ainda hoje, o bem comum de grandes camadas da classe privilegiada e - o que na prática é mais importante da classe média. Além disso, se entendemos como 'racionalismo prático' o modo de viver que reduz conscientemente o mundo aos interesses seculares do ego e o julga segundo esses interesses, tal estilo de vida era, e ainda é, característico dos povos do livre-arbítrio, tão profundamente entranhado nos italianos e nos franceses. Mas já estamos convencidos de que não é esse o terreno no qual prosperou a relação do homem com sua tarefa (Beruf), relação tão necessária ao capitalismo. Na verdade, a epígrafe de qualquer estudo sobre a racionalidade poderia ser este princípio muito simples mas esquecido: a vida pode ser racionalizada de acordo com finalidades muito diversas e seguindo direções muito diferentes. A racionalidade é um conceito histórico que contém um mundo de oposições. É preciso procurar de qual espírito nasceu determinada forma concreta de pensamento e de vida racionais; a partir do que se desenvolveu a idéia de tarefa (Berufsgedanke) e de dedicação ao trabalho profissional (Berufsarbeit) — tão tradicional, como já vimos, sob o aspecto puramente eudemonista do interesse pessoal - que, entretanto, foi e permanece um dos elementos característicos de nossa cultura capitalista. O que nos interessa aqui é exatamente a origem desse elemento irracional que ela contém, como toda a noção de Beruf".

Depois de situar na noção de Beruf (vocação ao mesmo tempo que trabalho, e por isso obrigação moral interiorizada pela qual a pessoa se desincumbe do trabalho) uma afinidade, o "parentesco profundo" entre a ética protestante e o espírito do capitalismo, Weber traça uma análise etimológica que confirma suas reflexões anteriores, isto é, a ausência dessa noção "nos povos em que predomina o catolicismo [...] nenhuma palavra de conotação análoga existe para designar o que nós, alemães, chamamos Beruf". Rejeitando a hipótese culturalista, que atribui uma parti- 
cularidade étnica ao "espírito germânico", Weber retraça o surgimento e as transformações da noção de Beruf a partir das traduções da Bíblia por Martinho Lutero, que produzem a passagem de uma noção eclesiástica à significação profana em quase todos os povos protestantes. A etapa decisiva no desenvolvimento dessa noção até seu "parentesco profundo" com o espírito capitalista é localizada por Weber nas relações conflitantes entre Lutero e Zwinglio, e nas seitas calvinistas, o que aliás explica por que "o catolicismo sempre considerou, e considera até hoje, o calvinismo como o verdadeiro adversário". Essa passagem etimológica permite precisar ainda mais o problema, portanto, o objeto de pesquisa. Weber rejeita uma solução simplista e reducionista: "Não se trata de propor uma tese tão irracional e doutrinária que pretenda que o 'espírito do capitalismo' (sempre no sentido provisório que damos à expressão) seja apenas o resultado de certas influências da Reforma, nem de afirmar que o capitalismo, como sistema econômico, seja uma criação da Reforma". O projeto de Max Weber se restringe a determinar a contribuição qualitativa do pensamento religioso ao espírito do capitalismo: "temos de tentar saber se certas 'afinidades eletivas' são perceptíveis entre as formas da crença religiosa e a ética profissional".

Depois de delimitado, no espaço infinito dos fenômenos empíricos, o problema a ser estudado pela abordagem indutiva, Weber pode dedicar-se, com a ajuda do método comparativo, à análise sistemática do problema, a começar pelas diferentes seitas protestantes (calvinismo, pietismo, metodismo, seitas batistas). Essa comparação sistemática ajuda a apresentar o duplo caráter do protestantismo - espírito comercial e piedade cristã - e, assim, refutar sobre bases mais sólidas do que as da introdução a oposição simplista entre o catolicismo "distanciado do mundo" e o protestantismo materialista. Além disso, ela permite descrever, historicamente, a dinâmica social da secularização e da racionalização internas da religião através dos conflitos teológicos referentes à predestinação:

“Em Calvino, esse decreto horrível não deriva da experiência religiosa, como em Lutero, mas das necessidades lógicas de seu pensamento; por isso, seu significado, a cada progresso, aumenta com a coerência lógica de uma meditação religiosa orientada apenas para Deus e não para os homens. Deus não existe para o homem, é o homem que existe para Deus. Aplicar as normas da 'justiça' terrestre a seus decretos soberanos não faz sentido e é um insulto à sua majestade". 
Ao recusar todo questionamento sobre o sentido que só pertence a Deus e que seria presunção tentar compreender, "a atividade social do calvinista desenvolve-se puramente ad majorem Dei gloriam". A conseqüência prática é que, para o calvinista,

\begin{abstract}
“Deus ajuda a quem se ajuda; e também, como se diz, 'cria' ele mesmo sua própria salvação, ou, para ser mais exato, a certeza da salvação. Essa criação da própria salvação impede o calvinista de viver 'dia após dia', como o leigo católico da Idade Média, e leva-o a organizar primeiro suas 'boas obras' e, mais tarde, toda a sua vida transformada em boa obra de modo racional, num sistema".
\end{abstract}

Irremediavelmente responsável por ela, o calvinista não dispõe mais "do sacramento da penitência, cuja função corresponde ao aspecto mais profundo do catolicismo". Ao eliminar esse sacramento, o calvinista ultrapassa uma etapa suplementar do processo de "desencantamento" do mundo, a eliminação da magia como técnica de salvação. A conformação cada vez mais racional da vida concretiza-se na exatidão, na pontualidade, no ascetismo, "na conformação sistemática e racional de toda a vida moral".

Depois de ter demonstrado o papel específico do calvinismo, entre todas as seitas protestantes, na formação do espírito ascético, Weber pode deter-se na análise mais minuciosa das afinidades entre esse espírito e o do capitalismo. Encontra uma primeira característica de destaque na relação específica com o tempo. A condenação do descanso, do ponto de vista da posse e do gozo da riqueza, é que dá origem ao mais grave de todos os pecados sob o aspecto ascético: o desperdício de tempo. Depois, vem a valorização do trabalho duro e consciencioso, a concepção puritana da vida conjugal e das relações sexuais, bases do homem moderno do mundo do trabalho:

\footnotetext{
"Assim como a estabilidade da profissão, expressamente recomendada pela importância que tem do ponto de vista ascético, transfigura eticamente a especialização moderna do trabalho (Fachmenschentum), também a interpretação providencial das oportunidades de lucro transfigura o homem de negócios. A indulgência do poderoso e a ostentação do novo-rico são identicamente detestadas pelo ascetismo. Em compensação, quanta aprovação ética para o sóbrio e burguês self-mademan...".
} 
Decorre daí também a tendência ascética antiautoritária, dirigida pelos burgueses contra a sociedade monárquica e feudal que protege "os que querem se divertir" e, nos tempos modernos, os ataques contra a moral proletária de classe e contra os sindicatos, sob o argumento de proteger "aqueles que desejam trabalhar".

“Para resumir o que dissemos até agora, o ascetismo protestante em ação no mundo opôs-se, com muita eficácia, ao gozo espontâneo da riqueza e impediu o consumo, sobretudo dos objetos de luxo. Em compensação, teve o efeito psicológico de livrar das inibições da ética tradicionalista o desejo de adquirir. Rompeu as correntes que entravavam essa tendência à compra, não apenas legalizando-a, mas também, como já expusemos, considerando-a como diretamente desejada por Deus".

Ao chegar ao fim de sua exposição, Weber insiste na secularização definitiva, depois de passada a onda de entusiasmo religioso: "O ardor da busca do reino de Deus começava a diluir-se gradativamente na fria virtude profissional; a raiz religiosa definhava, cedendo a vez à secularização utilitária [...] um ethos especificamente burguês da tarefa nascera". É aí que Weber pode estabelecer a realização da afinidade entre ética protestante e espírito do capitalismo, reunindo potencialmente patrões e operários:

"O ascetismo protestante [...] criou a única norma decisiva à sua eficácia: a motivação psicológica pela qual o trabalho como vocação (Beruf) constitui o melhor, senão o único, meio de garantir o estado de graça. Por outro lado, o ascetismo protestante legalizava a exploração dessa boa vontade para o trabalho, ao interpretar a atividade aquisitiva do empresário como 'vocação'. É evidente que a produtividade do trabalho, no sentido capitalista do termo, devia ser muitíssimo favorecida por essa busca exclusiva do reino de Deus através do dever profissional considerado como vocação, e pelo ascetismo rigoroso que a disciplina da Igreja impunha por sua própria natureza às classes não privilegiadas. Tratar o trabalho como 'vocação' tornou-se para o operário moderno uma atitude tão típica quanto a atitude correspondente do patrão em relação à aquisição [...]. Um dos elementos fundamentais do espírito do capitalismo moderno, e não apenas dele mas da própria civilização moderna, ou seja, a conduta racional baseada na idéia de Beruf, nasceu do espírito do ascetismo cristão — foi o que pretendíamos demonstrar [...]. O puritano queria ser um homem trabalhador - e somos forçados a sê-lo. Porque, quando o ascetismo foi transferido da cela dos monges para a vida pro- 
fissional e começou a dominar a moral secular, foi para participar da edificação do cosmos prodigioso da ordem econômica moderna. Ordem ligada às condições técnicas e econômicas da produção mecânica e maquinal que determina, com força irresistível, o estilo dos que nasceram nesse mecanismo - e não apenas daqueles diretamente envolvidos pela aquisição econômica. Talvez continue a determiná-lo, até que seja consumida a última tonelada de combustível fóssil. Na opinião de Baxter, a preocupação com os bens exteriores devia ser, para os santos, como um leve manto que se pode deixar cair a cada instante! Mas a fatalidade transformou esse manto em prisão de ferro".

Essa análise implacável coloca o leitor diante da origem e do reforço progressivo e inevitável da "prisão de ferro" onde ele vive. Podem-se tirar conclusões relativas ao futuro? Em um parágrafo de dez linhas, Weber esboça duas possibilidades no "fim desse processo gigantesco": primeiro, o aparecimento de profetas totalmente novos ou um forte renascimento de idéias e de antigos ideais; segundo, a petrificação mecânica, acrescida de uma espécie de vaidade convulsa: "Especialistas sem espírito, sensualistas sem coração, nulidades que imaginam ter atingido um nível de civilização nunca antes alcançado".

Depois de se aventurar em considerações prospectivas, o "domínio dos juízos de valor e de fé, do qual evitaremos sobrecarregar esta exposição puramente histórica", Weber esboça os problemas de pesquisa que decorrem de sua análise e que exigem maior desenvolvimento: "o significado do racionalismo ascético para o conteúdo da ética político-social, assim como para os tipos de organização e para as funções dos grupos sociais, desde o conventículo até o Estado [...] as relações com o racionalismo humanista [...] com o empirismo filosófico e científico [...] o progresso técnico e os ideais espirituais".

O último parágrafo do texto insiste em lembrar o caráter limitado do objeto estudado: a tentativa de estabelecer as causas do espírito do capitalismo deixou de lado as influências exercidas, em sentido inverso, pelas condições sociais e econômicas sobre esse "espírito". Weber explica que não pretendeu substituir a interpretação materialista por uma interpretação espiritualista, que "ambas pertencem ao domínio do possível; mesmo assim, na medida em que elas não se limitam ao papel de trabalho preparatório, mas pretendem trazer conclusões, tanto uma quanto a outra não servem à verdade histórica".

Quando se acompanha o modo de argumentação desse texto e se o compara ao da conclusão da pesquisa sobre os operários agrícolas e ao 
da aula inaugural na Universidade de Fribourg, percebe-se a mudança de perspectiva no trabalho de Max Weber depois de sua depressão nervosa. Partindo da constatação empírica da representação diferenciada dos católicos e dos protestantes na vida econômica e política alemã, ele discute primeiro todas as suas possíveis razões para conduzir lentamente o leitor ao objeto específico de sua análise, a afinidade entre a ética protestante e o espírito do capitalismo. Como modo de argumentação, esse procedimento indutivo é muito parecido com as primeiras seqüências descritivas das conclusões da pesquisa sobre os operários agrícolas. Mesmo assim, em vez de discutir o objeto de estudo em função de valores ou de objetivos (políticos) explicitamente anunciados, Weber o analisa sob várias perspectivas, a fim de melhor circunscrevê-lo e examiná-lo. Em vez de reduzir a complexidade, ele a amplia. Esse procedimento de construção de um Idealtype, no caso o do "espírito do capitalismo moderno", resulta da aplicação sistemática do método comparativo, que permite, pela complexificação do campo de análise, situar os traços evidentes de um fenômeno: seu "tipo ideal". Vamos acompanhar esse modo de argumentar. Uma primeira comparação de dados estatísticos permite reter o fator religioso como pertinente para explicar disparidades econômicas na Alemanha (comparação com fatores políticos, geográficos, educacionais, simples transmissão familiar da riqueza). Uma segunda comparação entre a mentalidade religiosa católica e a protestante permite constatar no seio do protestantismo a afinidade entre espírito comercial e piedade cristã. A afinidade confusamente percebida entre protestantismo e capitalismo exige, pois, uma análise mais fina: esta "cláusula de transição", em lugar de restringir, torna mais complexo o objeto de análise. A expressão "espírito do capitalismo" também é abordada de modo comparativo, o que permite distinguir os elementos constitutivos do espírito capitalista moderno (comparação histórica com outras economias de tipo capitalista, comparação entre tipos de empresário): o conceito de Beruf (vocação-profissão) expressa a ética capitalista e a diferencia da filosofia racional, puramente secular.

Depois de constatada no conceito de Beruf a afinidade entre ética protestante e espírito do capitalismo, Max Weber faz uma análise semântica, histórica e comparativa, o que lhe possibilita situar no calvinismo a origem dessa afinidade. Assim circunscrito o objeto de estudo - a afinidade ética entre calvinismo e capitalismo — - ele destaca essa hipótese pela comparação sistemática que efetua entre as diferentes seitas protestantes. Isso lhe permite retraçar a secularização das técnicas de salvação, desembocando em uma concepção racional da vida: planificação do tem- 
po, valorização do trabalho duro, concepção puritana das relações conjugais. A secularização definitiva desse ascetismo, primeiro na vida econômica, logo é estendida a todos os domínios e torna-se o traço evidente da civilização moderna. Os trechos dedicados a essa extensão ultrapassam, de certo modo, a construção propriamente dita do Idealtype "espírito do capitalismo". A comparação sistemática é deixada de lado e, ao contrário da construção do objeto propriamente dito, a reflexão especulativa sobre a evolução futura assemelha-se à argumentação política, negligenciando em sua demonstração todas as variações possíveis. O olhar lançado para o futuro renuncia à preocupação de complexidade. Essa retórica política não apenas elimina todos os aspectos do fenômeno analisado julgados pouco importantes (o que implica também a construção ideal típica), mas ainda leva a uma verdadeira simplificação. Isto se torna evidente no trecho que se propõe prospectivo. Como é de costume no pensamento tecnocrático, a visada prospectiva leva a uma espécie de cenário dualista: uma hipótese "catastrofista" que prolonga e reforça as imposições atuais, e uma outra hipótese, a do retorno ao irracionalismo. No fim do texto, Weber relativiza de novo essas conclusões. A cientifização do discurso de Max Weber procede, como se percebe, pelo abandono dos elementos prescritivos e prospectivos, e, onde tais elementos subsistem, por sua relativização.

A progressão desse texto leva à abertura de infinitas possibilidades, que sugerem novos objetos de pesquisa no decorrer da construção do Idealtype "espírito do capitalismo". Pelo método comparativo é possível filtrar quais elementos devem ser retidos para a construção do idealtype. Mas a construção do Idealtype "espírito do capitalismo" permanece provisória, sujeita a um aperfeiçoamento progressivo por meio de futuras pesquisas. Construída a partir de comparações sistemáticas entre as religiões cristãs, e em particular protestantes, a especificidade desse Idealtype poderia ser apenas o resultado do campo empiricamente observado. Para confirmar essa afirmação, seria necessário fazer uma comparação com a "ética econômica" (Wirtschaftsethik) de todas as religiões. Durante a Primeira Guerra Mundial, Max Weber começa essa tarefa imensa. Além de confirmar a validade da afinidade constatada entre ética protestante e espírito do capitalismo, tal comparação lhe permitirá destacar a estrutura formal da racionalização interna de todas as grandes religiões, isto é, de desenvolver seu Idealtype da religião. Ele apresenta essa construção, inicialmente, em suas "reflexões provisórias" (Zwischenbetrachtungen) redigidas em 1915-1916, e mais tarde no capítulo de Economia e Sociedade (1956:317-488) referente à religião. O método de comparação 
sistemática está na origem de uma leitura dinâmica que abre múltiplas pistas de pesquisa e questões. Diversifica e orienta a curiosidade em direções nem sempre intencionais no início da pesquisa. O interesse preponderante em A Ética Protestante, bem destacado no fim do texto, era contribuir para o estudo das origens do capitalismo, sem pretender chegar a um modelo sociológico do fato religioso.

Tradução: Estela dos Santos Abreu

\section{Notas}

* Esta é a segunda parte do artigo póstumo inédito de Michael Pollak, cuja primeira parte foi publicada no volume 2, número 1, abril de 1996, Mana - Estudos de Antropologia Social.

1 O texto do curso inaugural, de onde foram retiradas as citações a seguir, encontra-se em E. Baumgarten (1964:125 e ss.).

2 Podemos ler as traduções de Weber para o inglês e toda uma parte da interpretação parsoniana como uma reinterpretação de Weber nos cânones da teoria estrutural-funcionalista.

3 Essa concepção do Estado inspira toda a obra de F. Meinecke, em particular Die Entstehung des Historismus (1965) e L'Idée de la Raison d'État dans l'Histoire des Temps Modernes (1973:11-12). 


\section{Referências bibliográficas}

BAUMGARTEN, E. 1964. Max Weber, Werk und Person. Tübingen: Mohr.

LUHMANN, N. 1968. Soziologische Aufklärung. WDV: Opladen.

MEINECKE, F. 1965. Die Entstehung des Historismus. Munich: Oldenbourg. .1973. L'Idée de la Raison d'État dans l'Histoire des Temps Modernes. Genève: Droz.

MITZMAN, A. 1970. The Iron Cage. An Historical Interpretation of Max Weber. New York: Alfred Knopf.

POLLAK, M. 1986. "Un Texte dans son Contexte". Actes de la Recherche en Sciences Sociales, 65:69-75.

WEBER, Marianne. 1926. Max Weber: Ein Lebensbild. Tübingen: Mohr.

WEBER, Max. 1903/05/06. "Roscher und Knies und Logischen Probleme der Historischen Nationalökonomie" (IIII). Schmollers Jahrbuch für Gesetzgebung, Verwaltung und Volkswirtschaft, 27:1181-1221; 29:13231384; 30:81-120. . 1904. "Die Objektivität Sozialwissenschaftlicher und Sozialpolitischer Erkenntnis". Archiv für Sozialwissenschaft und Sozialpolitik, 19:22-87. . 1905. "Die Protestantische Ethik un der Geist des Kapitalismus" (I-II). Archiv für Sozialwissenschaft und Sozialpolitik, 20:1-54; 21:91-110. .1906a. "Zur Lage der Bürgerlichen Demokratie in Russland". Archiv für Sozialwissenschaft und Sozialpolitik, 22:234-353.

. 1906b. "Russlands übergang zum Scheinkonstitutionalismus". Archiv für Sozialwissenschaft und Sozialpolitik, 23:165-401.

. 1906c. " 'Kirchen' und 'Sekten' in Nordamerika". Chistliche Welt, 20(1): 558-562; 20(2):577-583.
_ .1913. "Gutachtliche Äusserung zur Werturteilsdiskussion". Verein für Sozialpolitik [publicado posteriormente como "Üer Einige Kategorien der Verstehenden Soziologie. Logos, IV:153-294]. .1916. "Die Wirtschaftsethik der Weltreligionen, Zwischenbetrachtung". Archiv für Sozialwissenschaft und Sozialpolitik, 41:335-421.

1920/21. Gesammelte Aufsätze zur Religionssoziologie (tome 1-3). Tübingen: Mohr.

1956. Wirtschaft und Gesellchaft (tome II). Tübingen: Mohr. 


\section{Resumo}

O artigo propõe situar a obra de Max Weber em suas condições sociais de produção, com base nas características de seu contexto familiar, da estrutura do campo universitário alemão e de suas relações com o mundo da política, acompanhando as transformações desse espaço social no qual se construiu a trajetória individual de Weber. Relacionando seus primeiros trabalhos, orientados para a intervenção nas discussões políticas e sociais da Alemanha do final do século XIX, com as mais conhecidas formulações posteriores do sociólogo alemão sobre as relações entre ciência e política, o artigo permite compreender a complexidade e as mudanças nessas relações não só na obra de Weber, mas também no mundo social no qual as formulações weberianas foram produzidas.

\section{Abstract}

This article proposes to situate Max Weber's work within the social conditions in which it was produced, studying the characteristics of his family configuration and the main traits in the structure of the German university field and its relationship to the world of politics, accompanying the changes in the social space in which Weber's individual trajectory was built. By relating his earlier works, oriented towards intervention in the political and social discussions of late 19th-century Germany, with this German sociologist's betterknown later formulations on the relations between science and politics, the article fosters an understanding of the complexity and changes in such relations, not only in Weber's work itself, but also in the social world in which his work was produced. 